\title{
0-401 当科で施行している嚥下機能評価の有用性についての検討
}

○草場雄基、増田聖子

熊本労災病院 耳鼻咽喉科

当科では誤嬹性肺炎罹患後や術後、口腔咽頭悪性腫瘍の治療後、脳神経疾患䍜患後の症例に対する経口摂取、飲水再開時 の燕下機能評価として嚥下内視鏡検査と嚥下造影検査を併用している。今回われわれは 1 年間に施行した検査結果を各項目 毎に比較し検査を併用して行う意義について検討した。症例は平成 30 年 1 月から 12 月までに検査を施行した 212 例を対象と し、検討項目は年齢、性別、食欲、咽頭反射の有無、舌運動、指示従命、嚥下内視鏡検查での咽喉頭の唾液貯留、喉頭知 覚、飲水試験での誤與の有無、また燕下造影検査での食物、水分摂取時の誤舆の有無を評価した。年齢、性別、食欲、舌運 動、指示従命、嚥下内視鏡検査、造影検査で有意差を認めた。また嚥下内視鏡検査で誤嚥を認め経口摂取が難しいかと思わ れた症例や指示が入らず内視鏡検査が不可能であった症例でも造影検査では䛊㦛なく嚥下が可能である症例が散見された。 燕下内視鏡検査、造影検査の両方が行える施設ではいずれも施行することでより確実な評価が可能になると思われた。

\section{0-402 High resolution manometry による曣下機能評価において必要な測定回数の検討}

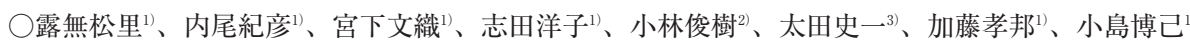
東京慈恵会医科大学 耳鼻咽䚐科学教室 ${ }^{1)}$ 、東京慈恵会医科大学付属柏病院 ${ }^{2)}$ 、太田総合病院 ${ }^{3)}$

目的：High resolution manometry（以下 HRM）による食道内圧の測定においては、10回の測定が推奨されてきた。しか し、咽頭〜上部食道括約筋の内圧測定においては、その測定回数に関する明確な基準は作成されていない。今回、HRMの 測定回数について必要十分となる測定回数について検討した。対象・方法：40人の健常被験者に経鼻的にHRMを挿入し、 Dry swallow、 $5 \mathrm{ml}$ water swallow 各10回ずつ施行し、上咽頭、舌根部、上部食道括約筋内圧を測定した。被験者ごとに 10 回のデータから平均值、標準偏差を求め、標準化を行った。各被験者において、標準化值の累積平均が $1 \mathrm{SD}$ 以内となるま でに要する回数を検討した。結果： $5 \mathrm{ml}$ 燕下時の上部食道括約筋圧最低值のみ、 5 回目の累積平均で $95 \%$ の被験者が $1 \mathrm{SD}$ 以内に収まった。他の項目は 4 回目で $95 \%$ の症例がさ1SD 以内に収まった。結論：5 回以上の測定を行えば、比較的正確な データが得られるのではないかと考えられた。

\section{0-403 重症心身障碍者における誤嬩防止術について}

○内田真哉、森本寬基、村井尚子、村上 怜、斉藤敦志、出島健司 京都第二赤十字病院 耳鼻咽喉科・気管食道外科

重症心身障碍者（以下、重身）の食事・栄養についても経口摂食に勝るものはないが、実際には嚥下障害が進行しても経 管栄養に頼る場面が多く、放置すれば廃用を来し嚥下機能自体を失いかねない。重身における誤嚥防止術はどの時期に、ど の術式を行うのが良いのか定説はない。

脳性麻疩による嚥下障害は緩徐に進行するが不可逆であり、訓練効果は見达めない。残存する嚥下機能を有効利用するこ とが掑食期間の延長と、QOL 維持には必要であり、そのための治療選択肢として誤嚥防止術は有用と考えられる。

一方、課題として重身の手術は術後合併症のリスクがあり、中でも気管腕頭動脈瘦は致命的なリスクである。また、重身 の家族に扔いては、たとえ実用会話が不能であっても、患者の声の喪失には抵抗があるため、患者側の価值観を理解する必 要もある。

当科では䛊嬹防止術として、声門下喉頭閉鎖術および嚥下改善型喉頭閉鎖術を開発し、すでに幅広い年齢、疾患において 効果を確認しているが、重身に対して行った例について検討する。

\section{0-404 輪状軟骨後板を温存した喉頭中央部切除術変法の長期予後の検討}

\author{
○加藤健吾、平野 愛、香取幸夫 \\ 東北大学 医学部 耳鼻咽喉・頭頸部外科
}

誤嚥防止手術は咽喉頭と下気道を外科的に分離し誤嚥を防止する手術の総称で、多くの術式がある。誤嚥防止手術に求め られる要件としては 1) 手技が容易かつ確実で低侵襲、2）安定した気管孔（気管カニューレ不要）、3）術後曣下機能の改 善、4）音声再獲得の可能性、等が挙げられる。攧中央部切除術は声門を含む喉頭中央部を摘出し、声門上で気道を閉鎖 する術式である。輪状軟骨は全摘出され低い燕下圧でも嚥下可能となるが、気管孔は喉頭全摘と同様で 2 割程度で狭窄を生 じていた。

私たちは輪状軟骨後板を温存した喉頭中央部切除術の変法を開発した。本術式は輪状軟骨後板を温存し気管孔の上・後・ 側壁として利用することで強固な気管孔を形成する一方、輪状咽頭筋は切除し、輪状軟骨後板は前頸部皮虐を用いてオトガ イ方向に牽引挙上することによって広い下咽頭と緩い頸部食道が形成されるため、嚥下機能の改善も期待できる術式であ る。私たちは2017年より15症例に本術式を実施してきた。1 年以上経過した 7 症例について気管孔の状態や経口摂取状況な ど長期予後を報告する。 


\title{
0-405 当科で施行した田山式声門閉鎖術に関する臨床的検討
}

\author{
○小林雅和 \\ 国立国際医療研究センター 耳鼻咽喉科
}

誤嚥防止術は、難治性誤嚥に対して気道と食道を分離し誤燕を防止する手術である。さまざまな手術手技が考案されてき ているが、当科では田山式声門閉鎖術を行ってきた。本術式の特徴は、Montgomery の原法を発展させたもので、切開した 甲状軟骨の前端を切除して喉頭の容積を減少させること、上下に分離した声帯を左右で縫合した後にさらに上下でも複数回 の縫合し、有茎筋弁を使用せずに上下の死腔をなくすことにある。今回は、2002年から2017年までに当科で田山式声門閉鎖 術を施行した48例に対して臨床的検討を行った。性別は男性37例、女性11例であり、平均年齢は50.6歳であった。現疾患は 先天性疾患18例、中枢神経障害11例、神経筋変性疾患10例、その他 7 例であった。術前には全例に重度の曣下障害を認め

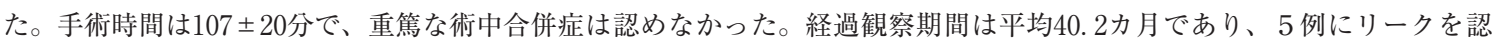
め、この内の 4 例では再手術を行った。最終的に 47 例において誤酀防止効果を認め、22例では術後にある程度の経口摂取が 可能となった。

\section{0-406 内視鏡下輪状咽頭筋切断術の術中出血に関する解剖学的知見}

○年俊一、栗田 卓、小野剛治、佐藤公宣、深堀光緒子、未吉慎太郎、佐藤文彦、三橋亮太、進 武一郎、 佐藤公則、梅野博仁

久留米大学 医学部 耳鼻咽㑨科・頭頸部外科

【背景】内視鏡下輪状咽頭筋切断術（ECPM）は低侵襲な術式として国内で普及過程にあるが、手技を習得するまでの時 期には術中出血に難渋することになる。これまで ECPM の術中出血の原因を明確に説明した報告はない。【目的】 ECPMの 術中出血に関する解剖学的知見を得る。【対象と方法】59歳男性の咽喉食摘標本を用いた。咽頭内腔から頸部食道まで食道 入口部を跨ぎバルーンで拡張させホルムアルデヒド液で固定した。硬性内視鏡と鉗子類を用いて、ECPM の術野で手術を シミュレーションし易出血部位を同定した。【結果】咽頭から食道までの全周性の粘膜剥離を行い輪状咽頭筋へアプローチ すると、同筋斜部の筋線維が正中で交叉する部分に一致して粘膜下組織が厚くなっており、太い静脈叢が同筋内へ流入して いた。【とめ】現行の ECPM 手技ではこの静脈叢を避けて輪状咽頭の筋腹正中部を明視下に置くことができないため、出 血を避ける、あるいは出血した際に止血操作での工夫が必要になる。

\section{0-407 喉頭気管分離・気管食道吻合術および気管食道シャント術併用（TED with TEP）例における 術後 QOL の検討}

○井口貴史 ${ }^{11}$ 、安達一雄 ${ }^{122}$ 、松原尚子 ${ }^{1)}$ 、山本陵太 ${ }^{11}$ 、梅崎俊郎 ${ }^{13)}$

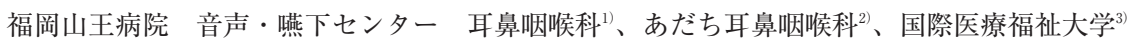

当科では、誤嬹防止手術の適応と判断された症例の中で、ADLがある程度保たれており、発声機能の維持を希望された ものに対しては、喉頭気管分離手術抢よび気管食道吻合術（tracheoesophageal diversion：TED）に加えて、一期的もしく は二期的に気管食道シャント術（tracheoesphageal puncture：TEP）を加える術式（TED with TEP）を行い喉頭音声温存に 成功している（Laryngoscope, 2018)。本術式では、無喉頭者に対するシャント発声ではなく、患者固有の声带を音源とす る点で格段に音声機能に優れている。また、他の誤嚥防止手術同様、嚥下反射がある程度残っている症例においては嚥下機 能の改善度も大きく、本術式をとることで QOL の著しい向上が期待できる。2014年の当センター開設以来、本術式を施行 した11例につき、音声および鱟下両面での客観評価と本人満足度について検討を行った。その結果、本術式は完全な䛊苝防 止でありながら本人の喉頭音声を温存できる画期的な術式であることが確認された。

\section{0-408 当院の摂食・嚥下・ロ腔ケア領域での多職種連携について}

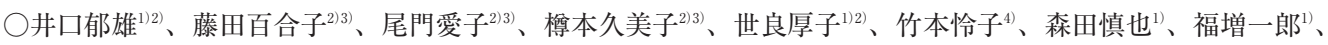
皆木正人 ${ }^{1)} 、$ 江草憲太郎 ${ }^{1} 、$ 綾田展明 ${ }^{1)}$

広島市立広島市民病院 耳鼻咽喉科 ${ }^{1)}$ 、広島市立広島市民病院 摂食・讌下・腔ヶア部会 ${ }^{2}$ 、

広島市立広島市民病院 看護部 ${ }^{3)}$ 、広島市立広島市民病院 研修部 ${ }^{4}$

在宅介護の現場で與下障害患者に対する多職種連携の有用性については言うまでもない。しかし、実際に各職種がどのよ うな貢献ができるか理解できているとは言い難い。これは、それぞれの職種がこの領域で具体的に何ができるのかなどにつ いての理解がそしいためと考える。

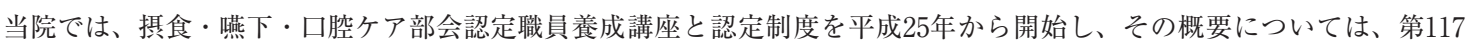
回 (名古屋) の本学会において報告した。平成 29 年度からは、認定職員がこの領域でさらに知識と技術を向上させることを 目的にスキルアップ研修会を開催している。研修会では、症例を提示してグループワークを行い、部会の各職種が解説を行 う方式を採用している。これらの研修会を通じて、相互理解がなされ、有意義な多職種連携が実現されていると実感してい る。スキルアップ研修会の実際について報告する。 